\section{Letter to the Editor regarding "Healthcare Personnel Attire in Non-Operating-Room Settings" by Bearman et al}

To the Editor-In the February 2014 issue of the journal, Bearman and colleagues, in conjunction with the Society for Healthcare Epidemiology of America Writing Group, published recommendations regarding healthcare worker (HCW) attire for acute care nonoperative hospital settings. ${ }^{1}$ While the authors thoroughly reviewed the literature, the resulting recommendations were disappointing. The authors noted that the topic "lacks the level of evidence required for a more formal guideline using the GRADE system" (p. 108) and that "the role of attire in cross-transmission remains poorly established" (p. 107), yet recommendations were made on several topics for which there are minimal to no data and even data against their recommendations. We are concerned about 3 issues.

First is the "bare below the elbows" (BBE) policy. This policy was adopted in the United Kingdom in 2007, with Scotland shortly following suit in $2008 .^{2,3}$ It received considerable backlash because of the lack of supporting evidence. In 2011, we published the results of a randomized controlled trial that found no difference in bacterial contamination or methicillin-resistant Staphylococcus aureus (MRSA) contamination of newly washed short-sleeved scrubs compared with infrequently washed white coats at the end of the 8-hour workday. ${ }^{4}$ One of the contentions of the BBE policy is that it should result in improved hand hygiene, in particular in the area of the wrist. We found no difference in either bacterial or MRSA contamination of the wrist between the 2 groups despite employing a BBE type of uniform. As Bearman and colleagues point out, 2 additional studies also reported similar results. ${ }^{5,6}$ Given this, it is clear that the recommendations are not evidence based but, rather, at best represent expert opinion and that these experts are ignoring data that go counter to their preconceptions. The medical community would have been better served by saying that no recommendations could be made at this time (similar to those that the authors made for the section on other HCW apparel).

Second is the issue of laundering. In our aforementioned study, we found that bacterial contamination ensues within hours of putting on a new uniform, suggesting that, to have any attire that is bacteria-free, HCWs would have to change their uniforms every few hours. ${ }^{4}$ We also found no association between the frequency with which white coats were changed or washed and the degree of bacterial contamination, despite physicians reporting that they washed or changed their white coats infrequently. Thus, whether one should wash his or her white coat daily, every other day, or, as the authors recommend, at a minimum of once per week is completely arbitrary.

Third, while no specific recommendations were made regarding antimicrobial scrubs, the authors presented only one study. Of the 2 studies presenting the most complete data, one is the article by Bearman and colleagues, ${ }^{7}$ which is referenced in the article, and the other is by our group. ${ }^{8}$ In our randomized controlled trial, we found no evidence that either of the 2 antimicrobial scrub products decreased bacterial contamination on HCW scrubs or skin compared with a standard scrub after an 8-hour workday. In addition, despite the fact that many HCWs were exposed to patients with antibioticresistant bacteria, these organisms were rarely cultured from their uniforms (either the standard scrubs or the antimicrobial scrubs). We attempted to study the product that Bearman and colleagues evaluated but were unable to as the company had insufficient stock available at the time we tried to purchase the product. We agree that additional studies are needed, but based on the results for the 2 types of scrubs we studied, the antimicrobial scrubs were more expensive and did not reduce bacterial contamination.

While we know that HCW attire becomes contaminated with bacteria, it is certainly not specific to the white coat. To date, there are no data to support or refute the hypothesis that HCW attire contributes to healthcare-associated infections (HAIs) or the contention that the BBE policy reduces HAIs or improves hand hygiene. Unless future studies indicate otherwise, we suggest that there are no data supporting the recommendations made by Bearman and colleagues regarding HCW attire with respect to reducing HAIs.

\section{ACKNOWLEDGMENTS}

Potential conflicts of interest. All authors report no conflicts of interest relevant to this article. All authors submitted the ICMJE Form for Disclosure of Potential Conflicts of Interest, and the conflicts that the editors consider relevant to this article are disclosed here.

\section{Marisha Burden, MD; ${ }^{1}$ Connie Price, $\mathrm{MD}{ }^{1}$ Richard K. Albert, MD $^{1}$}

Affiliation: 1. Department of Internal Medicine, Denver Health, Denver, Colorado; and University of Colorado School of Medicine, Aurora, Colorado. Address correspondence to Marisha Burden, MD, Denver Health, 777 Bannock, MC 4000, Denver, CO 80204 (marisha.burden@dhha.org). Infect Control Hosp Epidemiol 2014;35(6):743-744

(C) 2014 by The Society for Healthcare Epidemiology of America. All rights reserved. 0899-823X/2014/3506-0020\$15.00. DOI: $10.1086 / 676443$

\section{REFERENCES}

1. Bearman G, Bryant K, Leekha S, et al. Healthcare personnel attire in non-operating-room settings. Infect Control Hosp Epidemiol 2014;35:107-121. 
2. Department of Health. Uniforms and Workwear: An Evidence Base for Developing Local Policy. National Health Service, September 17, 2007. http://www.dh.gov.uk/en/Publicationsandstatistics /Publications/Publicationspolicyandguidance/DH_078433. Accessed January 29, 2010.

3. Scottish Government Health Directorates. NHS Scotland Dress Code. http://www.sehd.scot.nhs.uk/mels/CEL2008_53.pdf. Accessed February 10, 2010.

4. Burden M, Cervantes L, Weed D, Keniston A, Price CS, Albert RK. Newly cleaned physician uniforms and infrequently washed white coats have similar rates of bacterial contamination after an 8-hour workday: a randomized controlled trial. J Hosp Med 2011; 6:177-182.

5. Burger A, Wijewardena C, Clayson S, Greatorex RA. Bare below elbows: does this policy affect handwashing efficacy and reduce bacterial colonisation? Ann R Coll Surg Engl 2011;93:13-16.

6. Willis-Owen CA, Subramanian P, Kumari P, Houlihan-Burne D. Effects of "bare below the elbows" policy on hand contamination of 92 hospital doctors in a district general hospital. J Hosp Infect 2010;75:116-119.

7. Bearman GM, Rosato A, Elam K, et al. A crossover trial of antimicrobial scrubs to reduce methicillin-resistant Staphylococcus aureus burden on healthcare worker apparel. Infect Control Hosp Epidemiol 2012;33:268-275.

8. Burden M, Keniston A, Frank MG, et al. Bacterial contamination of healthcare workers' uniforms: a randomized controlled trial of antimicrobial scrubs. J Hosp Med 2013;8:380-385.

\section{Reply to Burden et al}

To the Editor-The letter by Burden et $\mathrm{al}^{1}$ in response to the Society for Healthcare Epidemiology of America (SHEA) expert guidance article on healthcare personnel (HCP) attire in non-operating-room settings ${ }^{2}$ raises an important question: should SHEA provide guidance in areas where available data are insufficient for evidence-based guidelines?

A core mission of SHEA is to advance the science of infection prevention, to help fill in evidence gaps in order to drive practice change and reduce infections. However, there are still far too many areas of uncertainty, and too little funding to address all of them quickly. In addition, given the multifactorial nature of healthcare-associated infection (HAI) risk, it is often very difficult to tease out the incremental risk associated with a single variable (eg, HCP attire). So the question arises, what should we do while awaiting better evidence?

I believe that the expertise of SHEA members is critical in helping to answer that question. A complete literature review and expert guidance (not guidelines) can assist infection prevention programs as they choose among options available to them (but without mandating approaches in the absence of sufficient evidence). The guidance on HCP attire does just that. The recommendations first reinforce the need for appropriately designed studies and emphasize the importance of making evidence-based HAI prevention measures the priority. Regarding specific attire practices, the guidance clearly states that the various approaches are optional and "should be voluntary" if institutions wish to pursue them.

Thus, rather than equating this guidance with the "bare below the elbows" policy adopted in the United Kingdom, Burden and colleagues should consider that the guidance provides hospitals the freedom to shape attire policies in a way that is consistent with their own priorities and based on their own weighing of the limited available evidence.

Providing guidance in the face of limited evidence is bound to generate debate, which is welcome and can help stimulate further research to clarify these areas of uncertainty.

\section{ACKNOWLEDGMENTS}

Potential conflicts of interest. All authors report no conflicts of interest relevant to this article. All authors submitted the ICMJE Form for Disclosure of Potential Conflicts of Interest, and the conflicts that the editors consider relevant to this article are disclosed here.

\section{Daniel J. Diekema, $\mathrm{MD}^{1, a}$}

Affiliation: 1. Division of Infectious Diseases, Department of Internal Medicine, University of Iowa Carver College of Medicine, Iowa City, Iowa. Address correspondence to Daniel J. Diekema, MD, Southwest 54 General Hospital, University of Iowa College of Medicine, 200 Hawkins Drive, Iowa City, IA 52242 (daniel-diekema@uiowa.edu).

${ }^{a}$ Current president of the Society for Healthcare Epidemiology of America.

Infect Control Hosp Epidemiol 2014;35(6):744-744

(C) 2014 by The Society for Healthcare Epidemiology of America. All rights reserved. 0899-823X/2014/3506-0021\$15.00. DOI: $10.1086 / 676444$

\section{REFERENCES}

1. Burden M, Price C, Albert RK. Letter to the editor regarding "Healthcare personnel attire in non-operating-room settings" by Bearman et al. Infect Control Hosp Epidemiol 2014;35:743-744 (in this issue).

2. Bearman G, Bryant $\mathrm{K}$, Leekha $\mathrm{S}$, et al. Healthcare personnel attire in non-operating-room settings. Infect Control Hosp Epidemiol 2014;35:107-121.

\section{Reply to Burden et al}

To the Editor-We read with interest the letter to the editor by Burden et $\mathrm{al}^{1}$ regarding the Society for Healthcare Epidemiology of America (SHEA) expert guidance article titled "Healthcare Personnel Attire in Non-Operating-Room Settings." Burden and colleagues take issue with the expert guidance statement with regard to 3 items. First, they object to a "bare below the elbows" (BBE) policy; second, they reject any recommendation regarding the frequency of laundering 